\title{
Rancang Bangun Sprayer Pestisida Menggunakan Pompa Air DC 12 V dan Panjang Batang Penyemprot 6 Meter
}

\author{
Annafiyah $^{1 *}$, Soffatul Anam², Misbakhul Fatah ${ }^{1}$ \\ ${ }^{1}$ Teknik Mesin Alat Berat, Politeknik Negeri Madura \\ ${ }^{2}$ Program Diploma Tiga Teknik Mesin Alat Berat, Politeknik Negeri Madura \\ Jl. Raya Camplong Km.4, Sampang \\ *E-mail: annafiyah0709@gmail.com
}

Diterima: 29-12-2020; Direvisi: 31-03-2021; Dipublikasi: 27-04-2021

\begin{abstract}
Abstrak
Tanaman padi merupakan komoditi utama pertanian di Indonesia. Salah satu proses perawatan tanaman padi adalah penyemprotan pestisida sehingga tanaman padi terhindar dari hama. Proses penyemprotan pestisida yang dilakukan para petani pada umumnya harus berjalan mengikuti alur tanaman padi sambil menggendong penyemprot dan bahan pestisida (sprayer knapsack). Tentu saja hal tersebut dapat membuat petani cepat lelah dan membutuhkan waktu yang lama. Berdasarkan masalah tersebut tujuan dari penelitian ini adalah untuk meningkatkan efektifitas kerja penyemprotan pestisida pada tanaman padi. Oleh karena itu, dilakukan penelitian rancang bangun sprayer dorong yang memiliki cakupan penyemprotan yang lebih luas. Sprayer ini didesain dengan menambahkan konstruksi rangka sebagai penggerak dan penopang sprayer, serta memiliki lengan dengan panjang 6 meter dan nozzle sejumlah 12 buah. Hasil dari rancang bangun sprayer Pestisida Menggunakan Pompa Air DC 12 V dan Panjang Batang Penyemprot 6 Meter adalah alat ini mampu melakukan penyemprotan secara luas dengan Kapasitas Lapang Efektif sebesar $0,73 \mathrm{ha} / \mathrm{jam}$. Alat ini mudah digunakan karena dirancang dengan menggunakan roda yang mudah dipindahkan.
\end{abstract}

Kata kunci: Nozzle; Pestisida; Sprayer; Sprayer Knapsack.

\begin{abstract}
Rice plants is the main agricultural commodity in Indonesia. One of the most common pest controls in Indonesia is by spraying pesticides. The process of spraying pesticides is generally done by following the planting pattern while farmers carrying the sprayer and pesticide material (sprayer knapsack) on their backs. This process is tiring and take a long time to finish. To improve spraying efficiency of rice plants sprayer, a study on the design of a push-able and wider - coverage sprayer was carried out. This sprayer is designed by adding a frame construction as a driving and support for the sprayer. Its arm is 6 meters in length and has 12 pieces of nozzles. The result from this study is first, sprayer design using water pump with DC $12 \mathrm{~V}$ and 6 meter long sprayer hose. From this sprayer design, spraying is done wider by a stretch of 6 meters and an effective field capacity of 0.73 ha / hour. This sprayer is easy to use because it's built with movable wheels so it helps farmers to move it faster
\end{abstract}

Keywords: Nozzle; Pesticide; Sprayer; Sprayer Knapsack.

\section{Pendahuluan}

Sejarah lahirnya ilmu-ilmu dalam lingkup teknologi pertanian dipicu oleh kebutuhan untuk pemenuhan pembukaan dan pengerjaan lahan pertanian secara luas. Bidang cakupan teknik pertanian antara lain alat dan mesin budidaya pertanian, mempelajari penggunaan, pemeliharaan dan pengembangan alat dan mesin budidaya pertanian. Tujuan utama dari penggunaan mesin-mesin ini adalah untuk meningkatkan produktivitas kerja petani dan mengubah pekerjaan berat menjadi lebih ringan [14].

Indonesia adalah negara agraris dengan salah satu komoditi utama adalah tanaman padi. Padi merupakan sumber pangan yang sangat penting bagi rakyat Indonesia. Harefa dalam [7] menjelaskan proses pemberian zat aditif (pupuk maupun pestisida) memiliki peranan penting dalam perkembangan industri pertanian. Proses ini berupa pengendalian yang bertujuan untuk mengoptimalkan pertumbuhan tanaman budidaya serta menjaga tanaman dari hama yang menghambat pertumbuhan dan produktivitas tanaman. Pengertian pengendalian (control) hama harus dibedakan 
Annafiyah dkk /Jurnal Rekayasa Mesin p-ISSN: 1411-6863, e-ISSN: 2540-7678 Vol.16|No.1|90-99|April|2021

dengan pemberantasan (eradication). Pengendalian hama dapat didefinisikan sebagai proses membatasi infestasi hama sedemikian rupa sehingga tanaman dapat dibudidayakan secara produktif dan efisien. Pengendalian bertujuan hanya menekan populasi hama sampai tingkat populasi yang tidak merugikan secara ekonomik atau tidak melampaui ambang ekonomik (economic threshold), sehingga sama sekali tidak bertujuan menekan populasi hama sampai nol. Sedangkan pemberantasan merupakan usaha mematikan seluruh hama yang ada baik sedang tumbuh maupun alat-alat reproduksinya, sehingga populasi hama sedapat mungkin ditekan sampai nol [10]. Pengendalian secara kimiawi adalah pengendalian hama dengan menggunakan bahan kimia yang dapat menekan laju pertumbuhan hama yang disebut herbisida. Aplikasi herbisida dapat dilakukan dengan cara penyemprotan (spraying), pengasapan (fogging), penghembusan (dusting), pencelupan (dipping), injeksi, penyiraman, dan penaburan. Pemberian pupuk dan pestisida berbentuk padat dapat dilakukan melalui akar tanaman [3].

Salah satu proses perawatan tanaman padi adalah penyemprotan pestisida sehingga tanaman padi terhindar dari hama. Penyemprotan ini adalah pemeliharaan tanaman padi yang sangat penting kerena dapat mempengaruhi hasil produktifitas pada saat panen [1]. Alat penyemprot (sprayer) pestisida tersebut adalah alat yang berfungsi untuk mengeluarkan cairan pestisida yang melewati pipa/selang yang dikeluarkan dalam bentuk butiran (droplet). Saat ini sprayer memiliki jenis yang bermacam-macam yaitu sprayer konvensional dan sprayer knapsack (sprayer dengan pompa yang digerakkan menggunakan tenaga listrik).

Petani menggunakan sprayer konvensional berupa sprayer tipe gendong dengan pompa manual (pompa diafragma) dengan tuas yang digerakkan naik turun oleh lengan kiri operator. Kapasitas tangki cairannya 15 liter. Tekanan pompa diafragma dari sprayer tersebut menghasilkan tekanan semprotan yang relatif rendah, apalagi pada saat operator sudah kelelahan untuk menggerakkan tuas pompanya. Dari hasil pengamatan, kinerja penyemprotannya kurang sempurna, butiran semprotnya tidak halus dan tidak sampai ke permukaan daun dengan merata. Tidak semua permukaan daun dapat tersemprot dengan baik. Selain itu, dengan menggunakan sprayer manual ini, operator hanya dapat menyemprot satu baris tanaman tebu dalam satu lintasan operasinya, sehingga kapasitas kerjanya rendah yaitu $0,37 \mathrm{ha} / \mathrm{jam}$. Sebagai akibatnya, target luasan kebun yang diaplikasi dalam waktu yang disediakan, tidak dapat dicapai [5]. Hal tersebut tentu membutuhkan waktu yang lama serta dapat membuat petani cepat merasa lelah karena menggendong tangki pestisida. Sedangkan penggunaan sprayer knapsack sangat dipengaruhi oleh kapasitas mesin pompa dan nozzle sebagai pembagi cairan yang disemprotkan. Keunggulan dari sprayer bermotor dengan katup debit tetap ini dapat menjaga ukuran butiran semprotan [12]. Pemiliha nozzle yang tepat didasari oleh sprayer yang digunakan, target yang akan disemprot, debit minimum droplet (butiran), formula pestisida yang digunakan, dan kualitas droplet (butiran). Deflector nozzle cocok digunakan pada sprayer knapsack (sprayer gendong) menurut hasil dari penelitian tersebut, nozzle ini memiliki kualitas droplet (butiran) dengan kualitas sedang, serta memiliki ukuran 217-353 $\mu \mathrm{m}$ [9]. Dalam mengendalikan hama, suatu penyemprot gendong dikatakan efektif jika sprayer tersebut mampu menurunkan penutupan hama terhadap lahan. Demikian juga efisiensi penggunaan sprayer, dikatakan efisien jika waktu yang dibutuhkan untuk menyemprot lebih singkat [5].

Penggunaan knapsack power sprayer memiliki mutu penyemprotan yang lebih baik dibandingkan sprayer gendong manual dengan membandingkan kapasitas rata-ratanya, sprayer manual memiliki kapasitas 0.37 ha/jam per orang, sedangkan knapsack power sprayer memiliki kapasitas mencapai 0.4 ha/jam per orang. Pengaruh kestabilan tekanan pada penerapan sprayer bermotor memiliki pengaruh yang baik pada efektivitas penyemprotan, hal ini dipengaruhi oleh sumber tenaga yang berasal dari motor bakar internal sehingga debit keluaran dan tekanan kerja lebih stabil, jika dibandingkan dengan sprayer manual yang menggunakan tenaga manusia sehingga tekanan yang dihasilkan tidak stabil 
Annafiyah dkk /Jurnal Rekayasa Mesin

p-ISSN: 1411-6863, e-ISSN: 2540-7678

Vol.16|No.1|90-99|April|2021

[2]. Menurut Harry [4], kapasitas keluaran adalah fungsi dari debit aliran pada nosel dan kecepatan sprayer. Akan tetapi faktor harga dan tingginya biaya operasional sprayer yang menggunakan energi motor bensin ataupun traktor menjadikan para petani kecil tidak mampu untuk menggunakan [7].

Penyemprotan dengan menggunakan sprayer gendong konvensional maupun dengan menggunakan tenaga listrik masih kurang efisien dalam waktu penyemprotan. Sebagai negara yang sebagian besar penduduknya bermata pencaharian sebagai petani, Indonesia dituntut untuk dapat mengikuti perkembangan teknologi yang ada. Menurut data hasil penelitian yang dilakukan oleh BPS tahun 2013 jumlah petani holtikultura di Indonesia adalah sejumlah 11,95 juta petani. Seiring dengan perkembangan teknologi, prinsip efisiensi dan efektifitas kerja sangat diutamakan [8].

Oleh karena itu untuk meningkatkan efektifitas kerja penyemprotan, penelitian ini menggunakan sparyer knapsack yang dirancang dengan menambahkan pipa yang terdapat beberapa nozzle serta menggunakan pompa listrik $12 \mathrm{~V}$. Pipa tersebut memiliki panjang 6 meter sehingga mampu mengatasi masalah waktu yang digunakan petani untuk pemupukan atau penyemprotan pestisida sehingga kapasitas lapang efektif dari penyemprotan meningkat. Dengan alat ini petani bisa menyemprot tanaman padi dengan area yang lebih luas sehingga waktu yang dibutuhkan akan lebih singkat.

\section{Material dan Metodologi}

Metodologi penelitian ini merupakan penelitian pengembangan yang digambarkan seperti pada diagram alir pada Gambar 1. Diawali dengan mengumpulan data dan studi literatur untuk merencanakan komponen alat maupun desain alat yang akan dirancang.

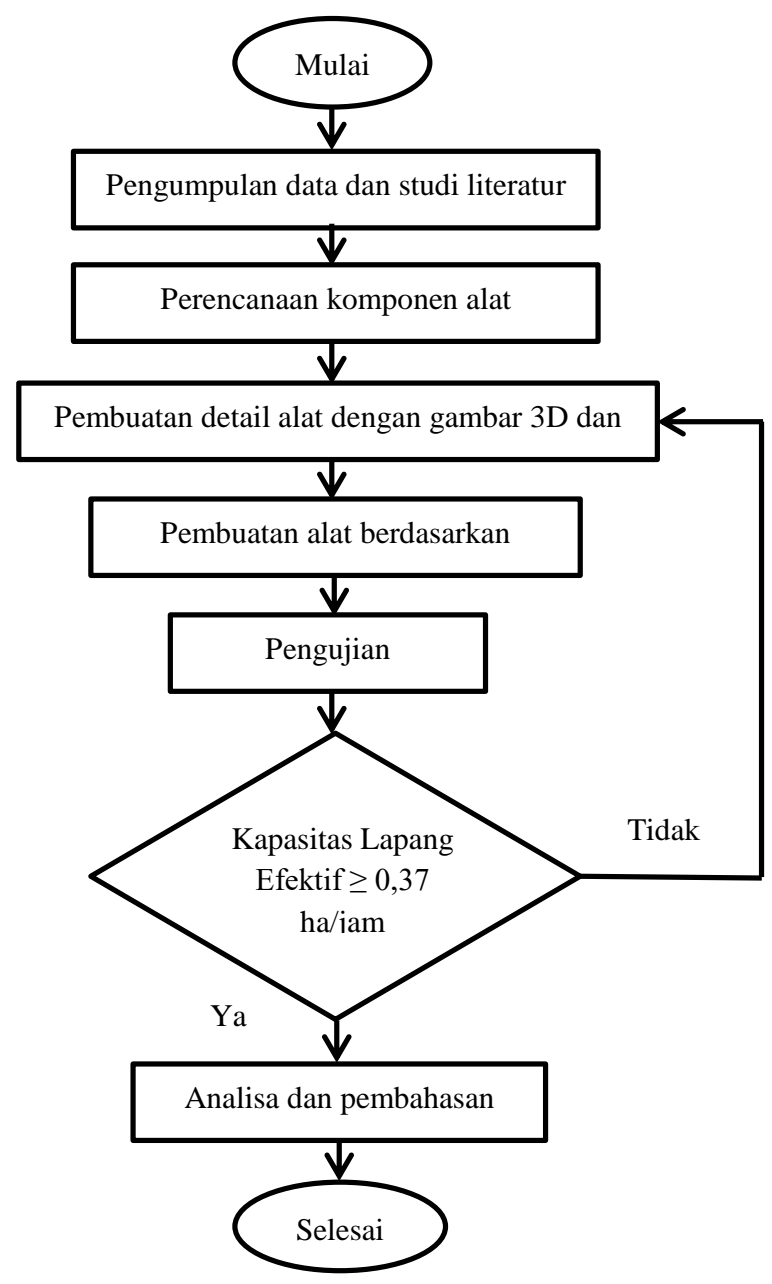

Gambar 1. Diagram alir penelitian 
Annafiyah dkk /Jurnal Rekayasa Mesin

p-ISSN: 1411-6863, e-ISSN: 2540-7678

Vol.16|No.1|90-99|April|2021

Berdasarkan perencanaan bahan-bahan yang akan digunakan adalah pipa besi, pelat besi, pipa PVC (Poly Vinyl Chloride), Sprayer knapsack, Pompa sprayer $12 \mathrm{~V}$ dan Nozzle. Desain dari rancang bangun sprayer dengan panjang lengan 6 meter memanfaatkan Pompa air DC 12 V yang didesain menggunakan Solidworks dapat dilihat pada Gambar 2 dan Gambar 3.

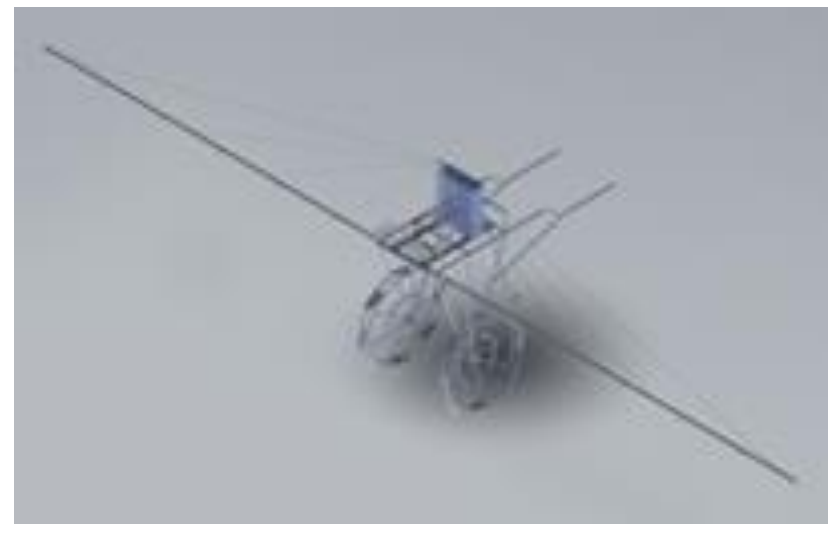

Gambar 2. Desain 3D Rangka Sprayer Pestisida

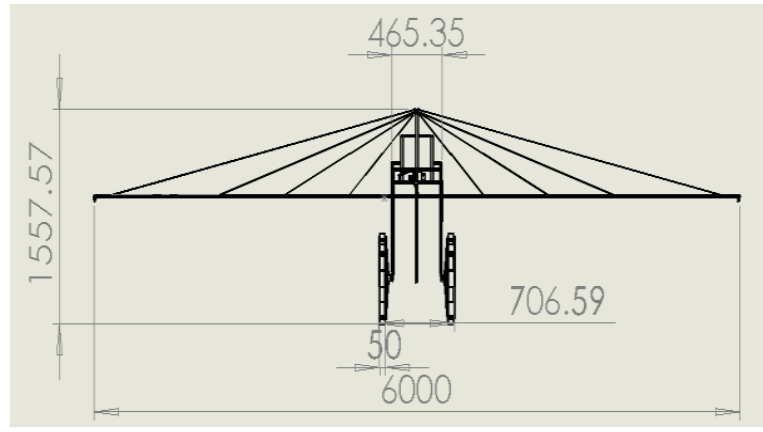

(a)

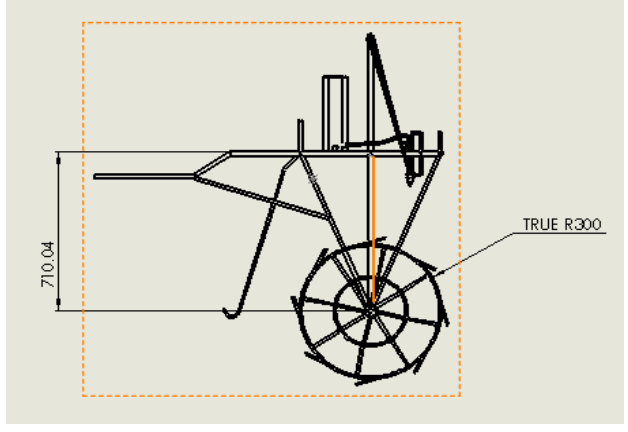

(b)

Gambar 3. Desain 2D Rangka Sprayer Pestisida (a) tampak depan (b) tampak samping

Gambar 4 menunjukkan rancangan sprayer lengkap dengan keterangan gambar yang terdiri dari 8 komponen utama. Rangka penopang berfungsi untuk menopang tangki sprayer serta terhubung dengan roda sebagai penggeraknya. Perhitungan gaya pipa penopang pada rangka batang digunakan rumus mekanika teknik truss. Berdasar gaya batang terhitung, perubahan panjang batang dihitung dengan menggunakan rumus Robert Hooke [13]. Perhitungan digunakan untuk menganalisa kekuatan rangka yang akan digunakan untuk menopang pipa sprayer 6 meter. Saluran irigasi berfungsi sebagai tempat aliran air dari tangki menuju nozzle. Tangki sprayer berfungsi sebagai penampung air yang akan dialirkan menuju saluran irigasi, dapat dilihat pada Gambar 5 (a). Pompa air berfungsi untuk mengalirkan air menuju saluran irigasi, dimana desain pompa air dapat dilihat pada Gambar 5 (b). Nozzle berfungsi untuk menjadikan air menjadi droplet (butiran air), dimana desain nozzle dapat dilihat pada Gambar 5 (c). Nozzle berfungsi sebagai penggerak alat serta penopang rangka.

Sprayer menggunakan penopang dari bahan besi pipa galvanis $3 / 4$ in, didesain dengan rangka yang terdapat roda sebagai penggerak. Rangka ini menopang tangki sprayer dan batang penyemprot sebagai saluran irigasi. Untuk mengetahui kapasitas rangka menopang beban maka diperlukan perhitungan untuk mencari tegangan ijin. Perhitungan tegangan ijin dapat dihitung dengan Pers. (1) dan (2), dimana variable $m, F, A, t$ dan $s f$ adalah massa, gaya, luas, 
Annafiyah dkk /Jurnal Rekayasa Mesin

p-ISSN: 1411-6863, e-ISSN: 2540-7678

Vol.16|No.1|90-99|April|2021

tegangan dan safety factor. Jika diketahui gaya rangka, gaya sprayer dan safety factor adalah $3,8 \mathrm{~kg}, 25 \mathrm{~kg}$, dan 2 , maka diperoleh tegangan ijin $0.00192 \mathrm{~kg} / \mathrm{cm}^{2}$.

$$
\begin{aligned}
& \alpha \mathrm{m}=\frac{\Sigma \mathrm{F}}{A} \\
& \alpha \mathrm{t}=\frac{\alpha \mathrm{m}}{s f}
\end{aligned}
$$

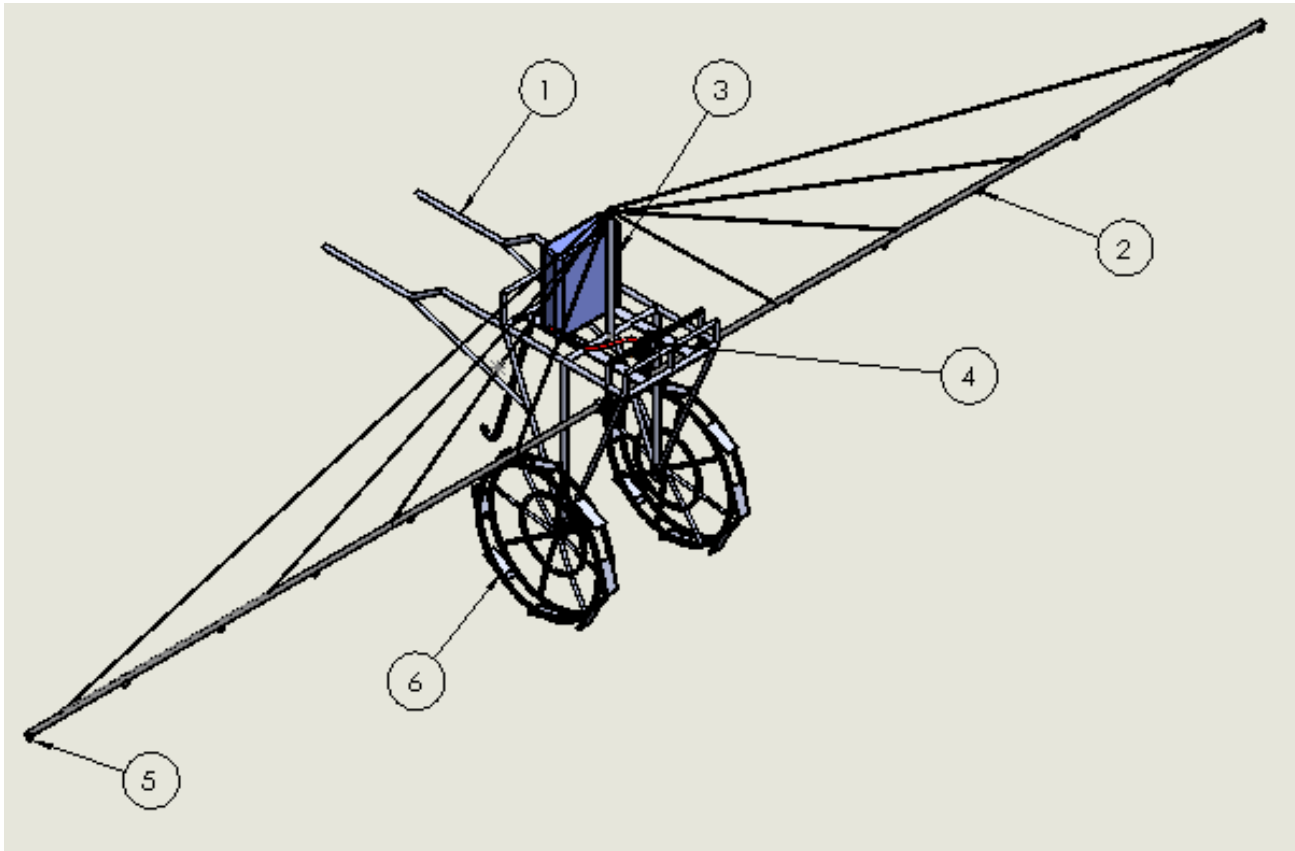

Keterangan:

1. Rangka penopang

2. Saluran irigasi

3. Tangki sprayer

4. Pompa air

5. Nozzle

6. Roda

Gambar 4. komponen Sprayer

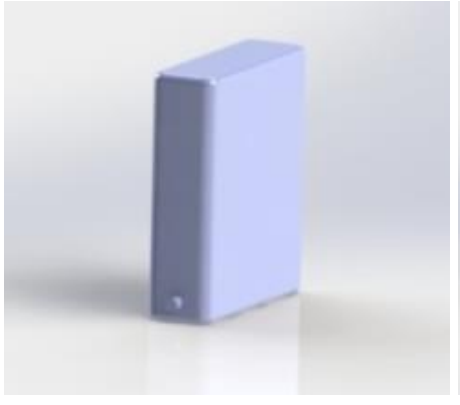

(a)

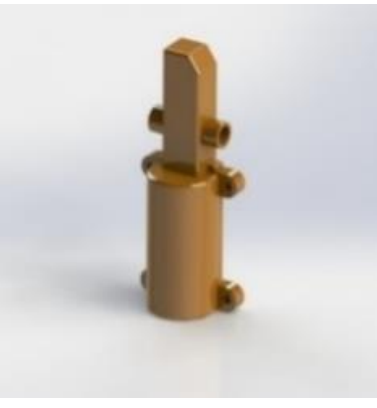

(b)

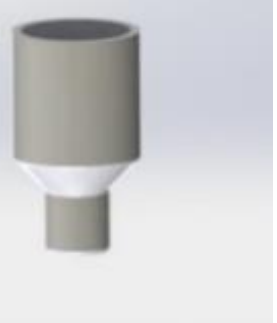

(c)

Gambar 5. Desain 3D, (a) tangki sprayer, (b) pompa sprayer, (c) nozzle sprayer

\section{Hasil dan pembahasan}

\subsection{Kapasitas Pompa Air}

Penyemprotan menggunakan Pompa air DC 12 V dengan debit air sebesar 2,9 Liter/menit dan Tekanan sebesar 60 Psi telah mampu membuat droplet yang halus. Sprayer menyemprotkan pestisida pada ketinggian $70 \mathrm{~cm}$ antara nozzle dan padi. Gambar sebaran droplet dapat di lihat pada Gambar 6. 
Annafiyah dkk /Jurnal Rekayasa Mesin p-ISSN: 1411-6863, e-ISSN: 2540-7678

Vol.16|No.1|90-99|April|2021

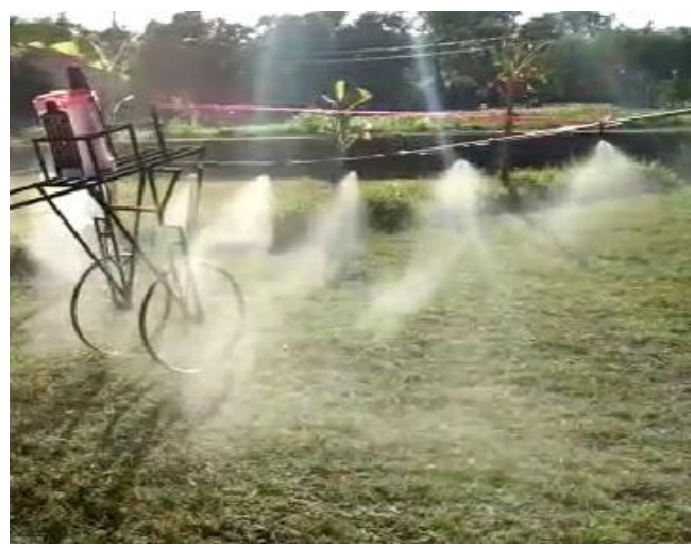

Gambar 6. sebaran droplet

\subsection{Menentukan jarak dan jumlah nozzle pada pipa 6 meter}

Nozzle merupakan katup yang berfungsi sebagai penyebar air dari pompa melalui pipa. Air menyebar dari nozzle dipengaruhi oleh lubang kecil yang disebut sebagai (droplet). Untuk keefektifan penyemprotan pada padi yang melalui saluran pipa dengan panjang 6 meter, diperlukan beberapa nozzle. Tabel 1 adalah spesifikasi full cone nozzle untuk menentukan jarak dan jumlah nozzle. Dari tabel spesifikasi full cone nozzle tersebut, pada perancangan alat dipilih sebuah jenis nozzle 460.646 yang memiliki lebar semprotan 38 inci dan tinggi semprotan 22 inci. Jarak nozzle yang terdapat pada batang penyemprot dengan panjang 6 meter dihitung dengan acuan lebar semprotan dalam overlap $100 \%$. Overlap bertujuan untuk menentukan lebar penyemprotan supaya penyemprotan lebih seragam. Jenis overlap dapat dilihat pada Gambar 10 [1].
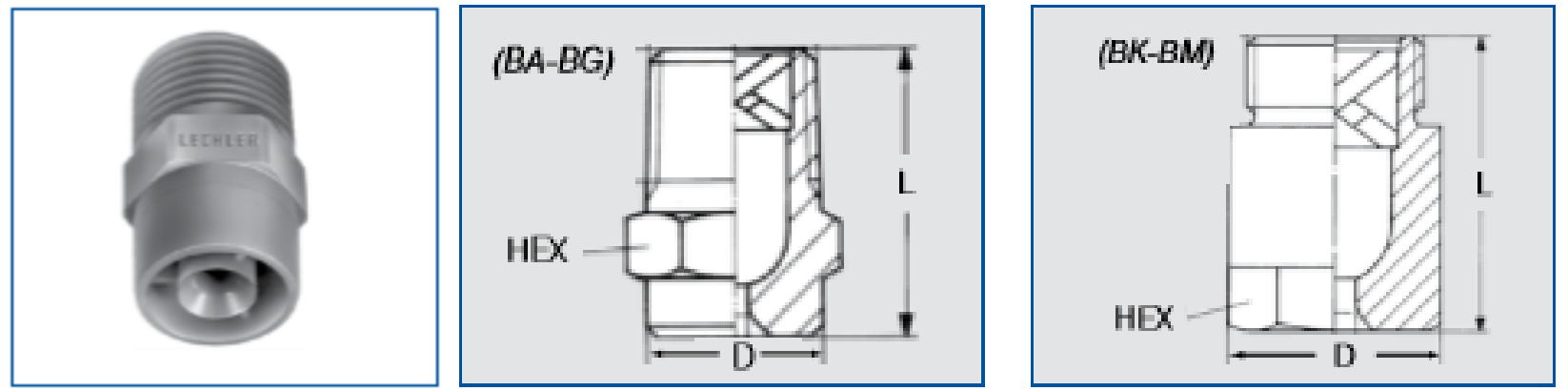

Gambar 9. Full cone nozzle

Tabel 1. spesifikasi Full cone nozzle [6]

\begin{tabular}{cccccc}
\hline \multicolumn{7}{c}{ Dimensions (In.) } \\
\hline Connection Code & Inlet (Male NPT) & L & D & Hex & Weight Brass (lb.) \\
\hline BA & $1 / 8$ & 0,71 & 0,51 & $9 / 16$ & 0.03 \\
BC & $1 / 4$ & 0,87 & 0,51 & $9 / 16$ & 0.04 \\
BE & $3 / 8$ & 1,18 & 0,63 & $11 / 16$ & 0,07 \\
BG & $1 / 2$ & 1,65 & 0,83 & $7 / 8$ & 0,15 \\
BK & $3 / 4$ & 1,97 & 1,09 & $1-1 / 8$ & 0,38 \\
BM & 1 & 2,20 & 1,32 & $1-3 / 8$ & 0,79 \\
\hline
\end{tabular}


Annafiyah dkk /Jurnal Rekayasa Mesin p-ISSN: 1411-6863, e-ISSN: 2540-7678

Vol.16|No.1|90-99|April|2021

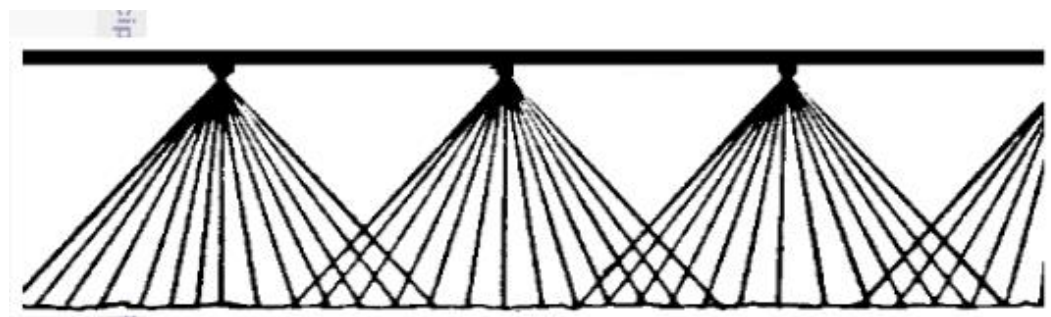

(a)

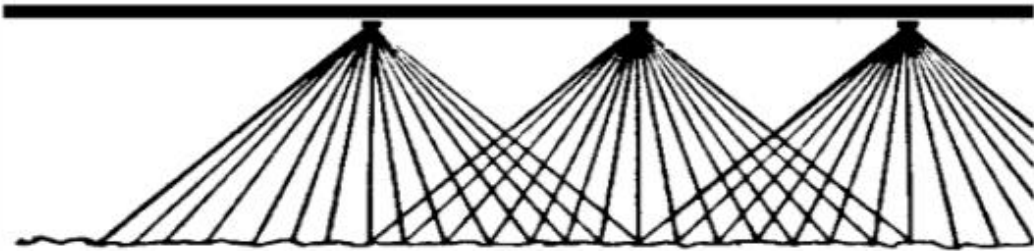

(b)

Gambar 10. (a) Overlap $50 \%$ (b) Overlap $100 \%$

Tabel 2. Ordering Number [6].

\begin{tabular}{|c|c|c|c|c|c|c|c|c|c|c|c|c|c|c|c|c|}
\hline \multirow{4}{*}{ 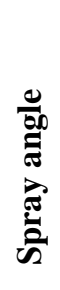 } & \multicolumn{9}{|c|}{ Ordering no. } & \multirow{4}{*}{ 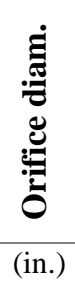 } & \multirow{4}{*}{ 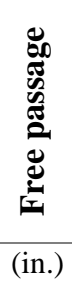 } & \multirow{2}{*}{\multicolumn{3}{|c|}{$\begin{array}{c}\text { Flow Rate } \\
\text { (Gallons Per } \\
\text { Minute) }\end{array}$}} & \multirow{3}{*}{\multicolumn{2}{|c|}{$\begin{array}{l}\text { Spray Diam. } \\
\text { D (in.) } \\
\text { @ } 30 \text { psi }\end{array}$}} \\
\hline & \multirow[t]{3}{*}{ Type } & \multicolumn{2}{|c|}{$\begin{array}{l}\text { Mat } \\
\text { No. }\end{array}$} & \multicolumn{6}{|c|}{ Connection } & & & & & & & \\
\hline & & \multicolumn{8}{|c|}{ Mate NPT } & & & & & & & \\
\hline & & $5 \mathrm{E}$ & 53 & $1 / 8^{\prime \prime}$ & $1 / 4 "$ & $3 / 8 "$ & $1 / 2 "$ & $3 / 4 "$ & $1 "$ & & & 10 & 20 & 30 & $\mathrm{H}=8$ " & $\mathrm{H}=20 ”$ \\
\hline & & & & & & & & & & & & psi & psi & psi & & \\
\hline $90^{\circ}$ & 460.526 & $\mathrm{O}$ & - & $\mathrm{BA}$ & - & - & - & - & - & .065 & .051 & .35 & .46 & .54 & 15 & 34 \\
\hline & 460.606 & $\mathrm{O}$ & - & $\mathrm{BA}$ & - & $\mathrm{BE}$ & - & - & - & .081 & .057 & .54 & .72 & .84 & 15 & 34 \\
\hline & 460.646 & $\mathrm{O}$ & - & - & $\mathrm{BC}$ & $\mathrm{BE}$ & - & - & - & .091 & .071 & .69 & .91 & 1.1 & 15 & 38 \\
\hline & 640.726 & $\mathrm{O}$ & - & - & - & $\mathrm{BE}$ & - & - & - & .116 & .079 & 1.1 & 1.4 & 1.7 & 15 & 38 \\
\hline & 640.746 & $\mathrm{O}$ & - & - & - & $\mathrm{BE}$ & - & - & - & .130 & .075 & 1.2 & 1.6 & 1.9 & 15 & 38 \\
\hline
\end{tabular}

Contoh pemesanan: $\quad$ Type + Material No + conn : Ordering No.

$460.526+5 \mathrm{E} \quad+\mathrm{BA}: 460.526 .5 \mathrm{E} . \mathrm{B}$

Untuk mengetahui jumlah nozzle diperlukan data spesifikasi nozzle untuk menghitung bentangan maksimal semprotan nozzle, panjang pipa, serta dielaborasi dengan overlap. Jenis overlap terdapat pada Gambar 10. Berdasarkan data spesifikasi nozzle (Tabel 2), jenis nozzle yang digunakan adalah tipe 460.646 jumlah nozzle dapat ditentukan dengan Pers. (3)

Jumlah nozzle $=\frac{\text { panjang pipa }}{\text { lebar semprotan overlap } 100 \%}$

Panjang pipa yang digunakan adalah $6 \mathrm{~m}$ atau $6000 \mathrm{~mm}$, lebar semprotan 38 inci atau 956,2 mm. Karena menggunakan overlap 100\%, maka lebar semprotan dibagi 2, lebar semprotan 956,2 /2 diperoleh 482,6 mm. Jarak antar nozzle yang diperoleh adalah 482,6 mm, maka dengan menggunakan Pers. (3) diperoleh jumlah nozzle yang digunakan sejumlah 12 buah. 
Annafiyah dkk /Jurnal Rekayasa Mesin

p-ISSN: 1411-6863, e-ISSN: 2540-7678

Vol.16|No.1|90-99|April|2021

\subsection{Spesifikasi Alat}

Pembuatan desain konstruksi alat ini merupakan proses modifikasi dari alat yang sebelumnya sudah ada, dengan menggunakan sprayer elektrik yang sudah ada ditambahkan konstruksi rangka sebagai saluran irigasi dan nozzle. Untuk menunjukkan spesifikasi alat dapat dilihat pada Tabel 2.

Tabel 2. Spesifikasi Alat.

\begin{tabular}{cll}
\hline No & Spesifikasi & Alat Sprayer Pestisida \\
\hline 1 & Penampung Air & Tangki Sprayer Kapasitas air 20 Liter, Tinggi tangki $50 \mathrm{~cm}$, lebar $21 \mathrm{~cm}$ \\
2 & Rangka & Pipa Galvanis $3 / 4$ in \\
3 & Pompa air & Dinamo sprayer debit $2.9 \mathrm{~L} / \mathrm{menit}$ \\
4 & Saluran irigasi & Kabel irigasi diameter $4 \mathrm{~mm}$ \\
5 & Penyemprot & Pipa stainless steel dengan panjang $6 \mathrm{~m}$ \\
\hline
\end{tabular}

\subsection{Kapasitas Lapang Teoritis (KLT)}

Efisiensi pengolahan lahan dipengaruhi oleh kapasitas kerja suatu alat. Kapasitas kerja alat didefinisikan sebagai suatu kemampuan kerja suatu alat atau mesin memberikan hasil (hektar, kilogram, liter) per satuan waktu [15]. Kapasitas Lapang Teoritis adalah rumus yang digunakan untuk mengetahui kapasitas pekerja dalam mengerjakan penyemprotan dalam 1 (satu) lahan dengan satuan ha/jam. Kapasitas penyemprotan perorang menggunakan sprayer konvensional standardnya 0,37 ha/jam [5]. Kapasitas Lapang Teoritis (KLT) dapat dihitung menggunakan Pers. (4) [11].

$$
K L T=v \times L
$$

KLT adalah kapasitas lapang teoritis (ha/jam), $v$ adalah Kecepatan rata-rata $(\mathrm{m} / \mathrm{s})$, serta L adalah Lebar kerja penyemprotan $(\mathrm{m})$. Pada proses pengujian dengan kecepatan rata-rata $0,36 \mathrm{~m} / \mathrm{s}$ dan lebar penyemprotan $1,5 \mathrm{~m}$. maka dapat diperoleh KLT sebesar 0,37 ha/jam.

\subsection{Kapasitas Lapang Efektif (KLE)}

Kapasitas lapang efektif adalah rumus yang digunakan untuk menghitung kapasitas penyemprotan unit secara real. Untuk mengetahui kapasitas lapang efektif harus mengetahui lama waktu kerja (WK) yang dapat dihitung dengan Pers. (5) [1].

$$
\mathrm{WK}=\left(\frac{l_{l}}{l_{k}} \times \frac{P_{1}}{v}\right)+\left(\left(\frac{l_{l}}{l_{k}}-1\right) \times t_{b}\right)
$$

WK adalah waktu kerja (jam), $l_{l}$ lebar lahan $(\mathrm{m}), l_{k}$ lebar kerja $(\mathrm{m}), P_{1}$ panjang Lahan $(\mathrm{m}), v$ kecepatan unit penyemprot $(\mathrm{m} / \mathrm{s})$, serta $t_{b}$ adalah waktu belok (s). KLE adalah kapasitas lapang efektif (ha/ jam) dan L adalah luas lahan (ha), Pers. (6).

$$
K L E=\frac{L}{W K}
$$

Pengujian alat dilakukan di area dengan panjang 25 meter dan lebar 10 meter. Jangkauan semprotan 6 meter menghasilkan waktu kerja (WK) 124, $08 \mathrm{~s}$, jika dikonversi menjadi jam hasilnya 0,034 jam. Dari perhitungan waktu kerja maka dapat dihasilkan KLE $=0,73$ ha/jam. 
Annafiyah dkk /Jurnal Rekayasa Mesin

p-ISSN: 1411-6863, e-ISSN: 2540-7678

Vol.16|No.1|90-99|April|2021

\subsection{Hasil Pengujian Alat Sprayer Pestisida}

Pengujian dilakukan di lahan dengan luas $250 \mathrm{~m}^{2}$, panjang lahan $25 \mathrm{~m}$ dan lebar $10 \mathrm{~m}$ dengan Kapasitas Tangki Alat 20 Liter serta Debit air 2,9 Liter/menit. Setelah dilakukan pengujian didapatkan data kecepatan dan lebar semprotan untuk dihitung serta mengetahui perbandingan dengan alat sprayer konvensional. Berikut adalah tabel data perbandingan hasil uji coba yang telah dilakukan. Tabel perbandingan dapat dilihat di Tabel 3.

Tabel 3. Hasil Uji Coba dan Perbandingan

\begin{tabular}{clc} 
No. & \multicolumn{1}{c}{ Nama Alat } & Kapasitas Lapang Efektif \\
\hline 1. & Sprayer konvensional & $0,37 \mathrm{ha} / \mathrm{jam}$ \\
2. & Sprayer dengan lebar semprotan $6 \mathrm{~m}$ & $0,73 \mathrm{ha} / \mathrm{jam}$ \\
\hline
\end{tabular}

Tabel 3 menunjukkan perbandingan waktu uji sprayer konvensional dengan sprayer dengan lebar semprotan 6 meter memiliki selisih kecepatan 0,36 ha/jam. Menunjukkan bahwa kinerja alat sprayer lebih cepat dari alat konvensional.

\section{Kesimpulan}

Berdasarkan hasil peneltian dan pembahaasan yang telah dilakukan mengenai Rancang Bangun Sprayer dengan Panjang Lengan 6 meter memanfaatkan Pompa air DC 12 V, diperoleh kesimpulan bahwa alat telah berhasil dibuat dengan menambahkan konstruksi batang penyemprot dengan lebar semprotan 6 meter. Hasil pengujian dari alat ini diperoleh nilai Kapasitas Lapang Efektif sebesar 0,73 ha/jam sehingga mampu meningkatkan efektifitas penyemprotan tanaman padi.

\section{Daftar Pustaka}

[1] Andremico, N. Rancang Bangun Dan Pengujian Unit Penyemprot Pada Alat Penyemprot Padi Tipe Balon. Sprayer, 2015.25.

[2] Aspar, Ghulam., Gatot, Pramuhadi. Studi Aplikasi Knapsack Sprayer, Knapsack Power Sprayer, Dan Boom Sprayer Di Pt Laju Perdana Indah, Palembang, Sumatera Selatan. IPB. 2012.

[3] Djojosumarto, P. Panduan Lengkap Pestisida \& Aplikasinya. Agromedia. 1, 13-31. 2008.

[4] Harry L. Field and John B. Solie. (2007). Introduction to Agricultural Engineering Third Edition. In Springer (3rd ed.). https://doi.org/10.1097/00010694- 195602000-00016.

[5] Hermawan, W., Kinerja Sprayer Bermotor dalam Aplikasi Pupuk Daun di Perkebunan Tebu. Jurnal Keteknikan Pertanian. Vol. 26, No. 2, Oktober 2012.

[6] Lechler USA. Klasifikasi Nozle. https://www.lechlerusa.com/en/resources/spray-facts/spray-patternclassifications/. (Diakses Pada tanggal 03 Januari 2020).

[7] Marno, Slamet, A., Eri, W., Modifikasi dan Pengujian Sistem Penyemprot Padi dengan Penambahan Pompa Elektrik. Jurnal Riset Sains dan Teknologi, Volume 4 No. 1, 1 - 6Maret 2020.

[8] Priyatmoko, A., Sri, W., Xander, S. Analisis Tekanan Tangki Sprayer Dengan Variasi besar Diameter Roda Dan Panjang Tuas Engkol Peluncur Dengan Menggunakan Satu Pompa Pada Sprayer Semi Otomatis. Jurnal wahana ilmuan, Untidar. Vol 1, no.1. 2016

[9] Salahudin, X., Sri, W., Miftahkul, K., Aris, P. Analisis Tekanan Pemompaan Mesin Sprayer Dorong Dengan Variasi Panjang Engkol Pompa Dan Diameter Roda. Prosiding SNST ke-8. 2017. P.47. 
Annafiyah dkk /Jurnal Rekayasa Mesin

p-ISSN: 1411-6863, e-ISSN: 2540-7678

Vol.16|No.1|90-99|April|2021

[10] Sukman, Y dan Yakup. Gulma dan Teknik Pengendaliannya. Jakarta: PT. Raja Grafindo Persada. 160 hal. 2002.

[11] Sulnawati, Endang., Sirajuddin, H, A., Asih, P., Analisis Teknis Dan Kajian Ergonomika Berdasarkan Antropometri Pada Penggunaan Traktor Tangan Untuk Lahan Sawah. Jurnal Ilmiah Rekayasa Pertanian dan Biosistem, Vol.4, No. 2. September 2016.

[12] Tahir, A.R., F.H. Khan, A.A. Khan. Effect of constant flow valves on performance of pesticide sprayers. International Journal of Agriculture and Biology Vol. 5(1): 49-52. 2003.

[13] Tetekonde, Stevan., Rudy, D., Rita, I. Analisis Kapasitas Lentur Sistem Penulangan Rangka Dengan Metode Finite Element. Fakultas Teknik Universitas Hasanuddin, Makassar. 2017.

[14] Yulia, Usrah, M., Iqbal., Daniel. Uji Kinerja dan Analisis Biaya Traktor Roda 4 Model AT 6504 dengan Bajak Piring (Disk Plow) pada Pengolahan Tanah. Program Studi Teknik Pertanian. Universitas Hasanuddin Makassar.

[15] Zulpayatun., Cahyawan, C., Guyup, M., Performansi Traktor Tangan Roda Dua Modifikasi Menjadi Roda Empat Multifungsi (Pengolahan Dan Penyiangan) Untuk Kacang Tanah Di Kabupaten Lombok Barat. Jurnal Ilmiah Rekayasa Pertanian dan Biosistem, Vol.5, No. 1. Universitas Mataram. Maret 2017. 